\title{
セメントモルタルのセラミック化に関する基礎的研究 STUDY ON CERAMICS OF CEMENT MORTAR
}

\author{
三田紀行*, 山本康弘**, 大沢清八*** \\ Noriyuki MITA, Yasuhiro YAMAMOTO \\ and Seihachi OSAWA
}

\begin{abstract}
This paper is intended to develop and study the technology to produce the ceramics of cement mortar by using cement, fritted glaze, silica fume and some special sands. The specimens were casted $(2 \times 2 \times 8 \mathrm{~cm})$ with this mortar. And after curing, they were fired at $940{ }^{\circ} \mathrm{C}$ or $1000{ }^{\circ} \mathrm{C}$ for two hours to measure the properties of these specimens before and after firing.

As the result, the fritted graze of low fusing point with $20 \%$ frits/cement ratios and of 5 $\sim 8 \%$ silica fume/cement ratios was found to be most suitable for these ceramics of cement mortar. And the most suitable firing temperature for the properties of these specimens after firing is found to be $1000^{\circ} \mathrm{C}$. And the surface of these mortar was tested to be colored with the glaze by these firing.
\end{abstract}

Keywords : cement-concrete, ceramics, fritted glaze , firing , strength, silica fume

セメント・コンクリート, セラミックス, フリット釉, 焼成, 強度, シリカフューム

\section{1 . 序論}

近年、建築物は多様化・高機能化が進み、従来に増し てその本来の機能に対して様々な要求が求められている。 特に大都市における集合住宅やオフィスビルの高層化・ 複合化が進み、より一層災害に対して強い建物が要求さ れている。一般にコンクリートを用いた建物は耐火建築 物として火災に対して強いとされている。しかしセメン

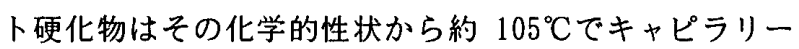
水扰よびゲル水を失い、さらに約 $250 〜 350^{\circ} \mathrm{C} て ゙ A I_{2} 0_{3} や$

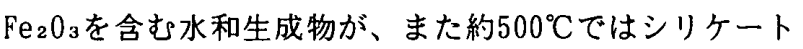
水和生成物および $\mathrm{Ca}(\mathrm{OH})_{2}$ が脱水され、強度が急激に隇 少する。 ${ }^{11}$ 事実火災にあったために軀体の補修を必要と する場合も多い。特に高層建築物の場合、事実上補修が 不可能なことも考えられ、軀体自体に今まで以上の耐火 性能が要求されるものと思われる。

一方最近では、建物に対して上記のような機能的要求 だけでなく、文化的要求の所産として美しさが求められ
る傾向が増大している。意匠材料としてタイル・石材等 が多く用いられているが、これらは色彩鮮やかで経時変 化が少なく、安定感があり耐久性に優れている。しかし 一般には小さなブロック片を張り付けるため工費が高く、 豩落等の久損も生じやすい。このためコンクリートの表 面に直接釉薬を施釉できればこれらの問題が解決できる。

そこで本研究は、セメント硬化物にほうろうびきに使 用されるフリット釉等のセラミック材料を、あらかじめ 混入してセラミック化し耐熱性の向上を困るとともに、 このセメント硬化物の表面を色釉薬により施釉し焼成し て、色彩表現豊かで経時的変化の少ない磁器質の施釉面 とし、そのまま意匠材として使用可能にすることなどを 目的としたもので、今回はこのうちセメントのセラミッ ク化についての基礎的な研究と施釉方法についての研究 を行ったものである。

2.セメントモルタルのセラミック化実験

2.1.フリットによるセメントモルタルのセラミック化

\footnotetext{
* 職業能力開発大学校建築工学科 助手 ·工修 Research Assoc., Dept. of Architectural Engineering, Polytechnic Univ., M. Eng.

** 東京都立大学工学部建築学科 教授・工博 Prof., Dept. of Architecture, Faculty of Engineering, Tokyo Metoropolitan Univ., Dr. Eng.

*** 相武生コン株式会社 Soubu Namacon Company
} 


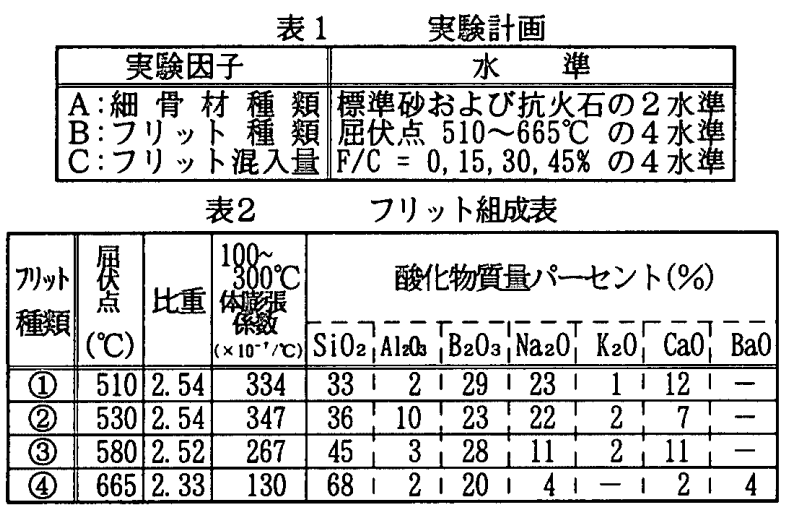

ここではセメントモルタルのセラミック化を図るにあ たって、モルタルに混入するフリットの混入量（セメン トに対するフリットの重量比で F/Cで表す) ・フリット の種額およびモルタルの主要構成材料である細骨材の種 頻について、焼成前後の物性の変化との関係を検討した。

\subsection{1. 実鑒概要}

実験は表 1 に示すように、2 種頻の細骨材に対しフリ ットの種類を 4 種類、フリットの混入量を 4 通りとして、 それぞれの組み合わせに対し試験体を作成した。なお圧 縮・曲げ強度試験結果に関しては各水準の母平均の推定 を行うとともに分散分析による解析を行った。

\subsection{2. 使用初䍈}

実験には普通ポルトランドセメントを用い、フリット には表 2 および図 1 に示す 4 種類を用いた。これらは屈 伏点が比較的低い510 $665^{\circ} \mathrm{C}$ のものである。

細骨材にはJIS R 5201(セメントの物理試駼方法)に用 いる豊浦産標準砂と最大粒径 $2 \mathrm{~mm}$ 以下の東京都新島産の 抗火石（単位容穦質量: $1.27 \mathrm{~kg} / \ell$, 組粒率: 1.79 ) を使用 した。この抗火石は流紋岩の一種で、火成岩であるため 耐熱性にすぐれている。また多孔質なため軽量で保温性 があり、同時に酸に対する抵抗が大きい。化学成分とし てはSi $0_{2}$ が約 $75 \%, \mathrm{Al}_{2} \mathrm{O}_{3}$ を約 $13 \%$ 含んでおり、代表的な

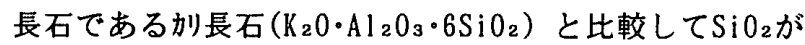
$10 \%$ 程多〈、 $\mathrm{Al}_{2} \mathrm{O}_{3}$ が $5 \%$ ほと少ない組成を示している。 ${ }^{3)}$ ４）

\subsection{3.試煥体の作成}

試験体は標戟砂および抗火石ともにセメント:砂 $=1: 2$ のモルタルとし、これに 4 種頜のフリットについてそれ ぞれ対セメント重量比で $15 \%, 30 \%, 45 \% を$ 外割りで混入し たもの、および比較用として無混入のものの 4 通りとし、 合計 32 種䫛となった。各調合とも図 2 に示すようにモル

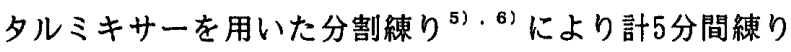
混ぜ、フロー値 $125 \pm 5$ となるよう繙り混ぜ水量を調節した。 その場合の各調合の水セメント比は図 3 の通りである。

試験体はJIS A 6904(せっこうプラスター)に準じた寸 法 $2 \times 2 \times 8 \mathrm{~cm}$ の角柱状のものを、2 時間の焼成用および 4 週 強度試験用の 2 通りについて各 3 本を作成した。これら の試験体は成型後 24 時間で脱型したのち、材齢 7 日まで 水中善生 $\left(20^{\circ} \mathrm{C}\right)$ を行い、以後材跲28日まで湿空中 $\left(20^{\circ} \mathrm{C}\right.$,

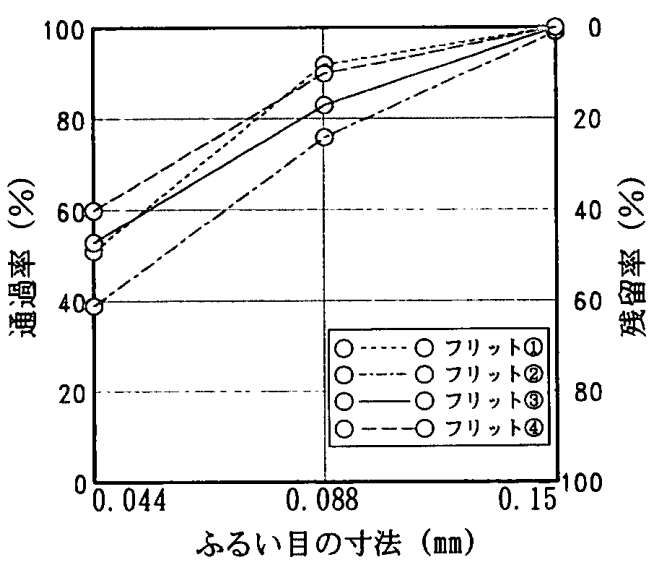

図 1 フリットのふるい分け試験結果

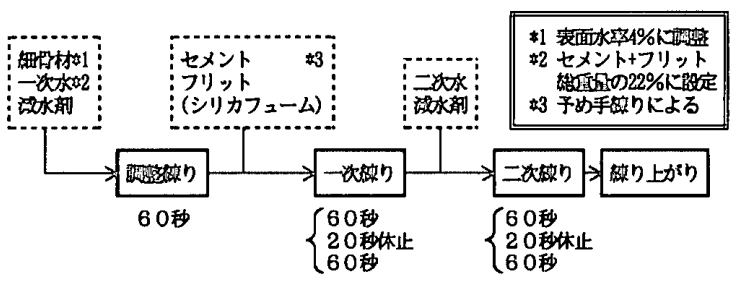

図2 モルタルの練り混ぜ方法

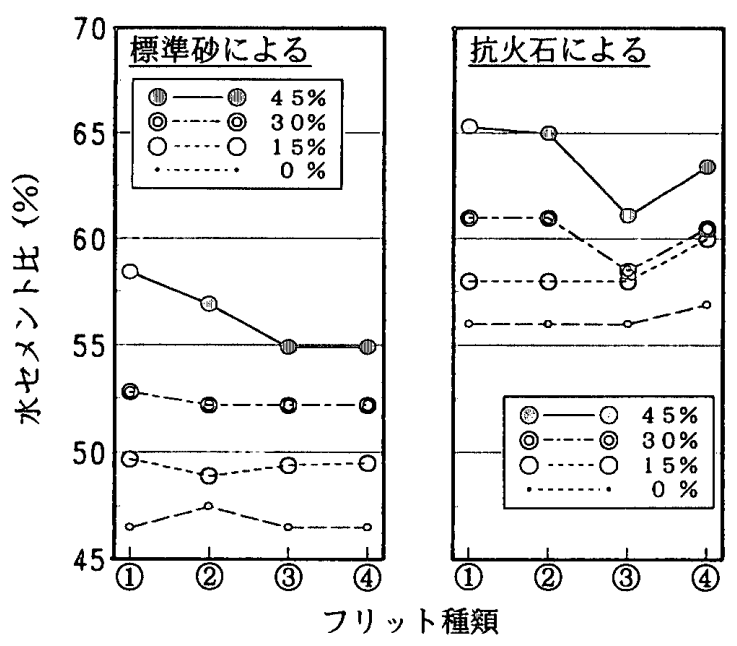

図3フリット混入量と水セメント比の関係

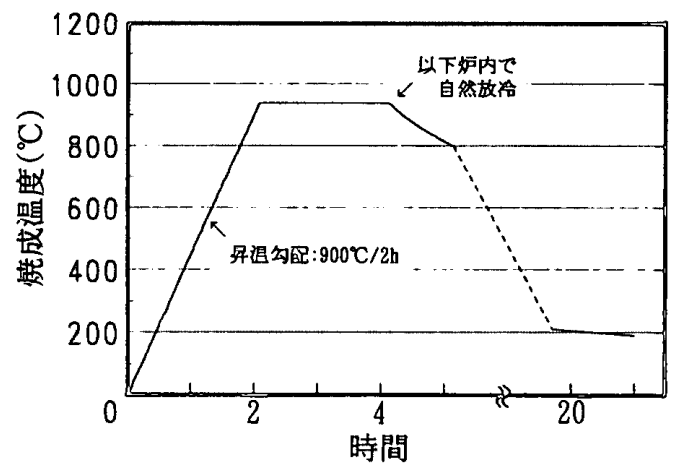

図4昇温曲線 
RH80\%)で盖生した。その後 $110^{\circ} \mathrm{C} の$ 定温乾燥器中で 24 時 間乾燥を行い、焼成時まで乾燥剂入りのデシケータ内に て保存した。

\subsection{4.試験体の焼成および試験}

試験体の焼成は火災時の急激な温度上昇にも対処可能 かを判断するために、常温の試験体をマッフル炬中に挿 入したのち、図 4 に示すように 2 時間で $900^{\circ} \mathrm{C}$ になるよ うに加熱し、 $940^{\circ} \mathrm{C}$ とったのちそのまま 2 時間温度を 維持し焼成した。焼成後は炉内で自然放冷させ、炬内温 度が $200^{\circ} \mathrm{C}$ 以下になってから試験体を取り出し、各試験 を行うまで前述のデシケータ内で保管した。

試験項目は盖生期間中より各焼成段階を通じてノギス による長さ測定および重量測定を行った。強度試験は2 $2 \times 2$ $\times 8 \mathrm{~cm}$ の試験体を焼成前後で前述のJIS A 6904に従って曲 げ試験を行い、その切片を用いて前述のJIS R 5201に準 じ、加圧面積を $4 \mathrm{~cm}^{2}$ として圧縮試験を行った。

\subsection{5.実験結果および考察}

図 5,図6に標準砂、抗火石それぞれに関して焼成前後 におけるフリットの混入量と王縮・曲げ強度の結果を示 す。これよりフリットの混入量が多くなると焼成後の強 度减少が小さくなり、焼結反応が進んでいることが推測 される。特に混入量が45\%のものは焼成前後での強度差 が少なく安定していることがわかる。そこで各試験体の 圧縮・曲げ試験結果に対する細骨材の種類, フリットの混 入量, フリットの種類の影響について分散分析を行った。 その結果は表 3 に示すように圧縮・曲げ強度ともに細 骨材の種類，フリットの種類およびフリットの混入量の 各因子いずれに関しても危険率 $1 \%$ で有意差を示してお り、各因子間に関しては交互作用が認められている。

特に細骨材の種類の影響は大きく、図 6 より細骨材と して抗火石を用いたものが標準砂を用いたものを大きく 上回っていることがわかる。同様にフリットの混入量も 各種強度に及ぼす影響は図 7 に示すごとく非常に大きく、 フリット混入の効果は約 $30 \%$ 程度から顕著であることが わかる。さらにフリットの種類の影響であるが、図 8 に 示すように圧縮および曲げ強度に及ぼす影響はかなりあ り、今回の実験ではフリット(3)およびフリット(1)を用い たものが高い値を示している。これは図 9 に示すフリッ トの種類とフリットの混入量の影響からも明らかで、フ

表 3 生縮・曲げ強度の分散分析表

\begin{tabular}{|c|c|c|c|c|c|c|}
\hline \multirow[b]{2}{*}{ 要 因 } & \multicolumn{2}{|c|}{ 王縮強度 } & \multicolumn{2}{|c|}{ 曲げ強度 } & \multirow[b]{2}{*}{$\underset{(5 \%)}{F}$} & \multirow[b]{2}{*}{$\underset{(1 \%)}{F}$} \\
\hline & 息 & 分散比 & 自 & 分散比 & & \\
\hline 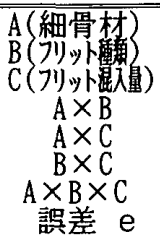 & $\begin{array}{r}1 \\
3 \\
3 \\
3 \\
3 \\
9 \\
9 \\
62\end{array}$ & $\begin{array}{r}169.4 * * \\
15.1 * * \\
350.5 * * \\
4.6 * * \\
28.9 * * \\
15.8 * * \\
2.4 * \\
-\end{array}$ & $\begin{array}{r}1 \\
3 \\
3 \\
3 \\
3 \\
9 \\
9 \\
62\end{array}$ & $\begin{array}{r}621.0 * * \\
29.0 * * \\
572.9 * * \\
25.2 * * \\
11.5 * * \\
25.8 * * \\
9.3 * * \\
-\end{array}$ & $\begin{array}{l}4.00 \\
2.76 \\
2.76 \\
2.76 \\
2.76 \\
2.04 \\
2.04\end{array}$ & $\begin{array}{l}7.08 \\
4.13 \\
4.13 \\
4.13 \\
4.13 \\
2.72 \\
2.72\end{array}$ \\
\hline 計 & 95 & - & 95 & - & - & - \\
\hline
\end{tabular}
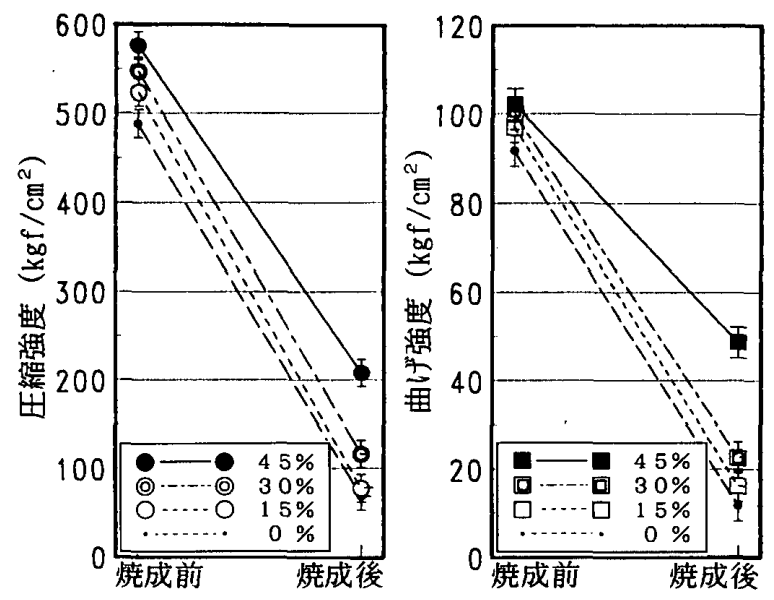

図 5 焼成前後におけるフリッ⿻上混入量と強度変化の関係 （標準砂細骨材を使用した場合）
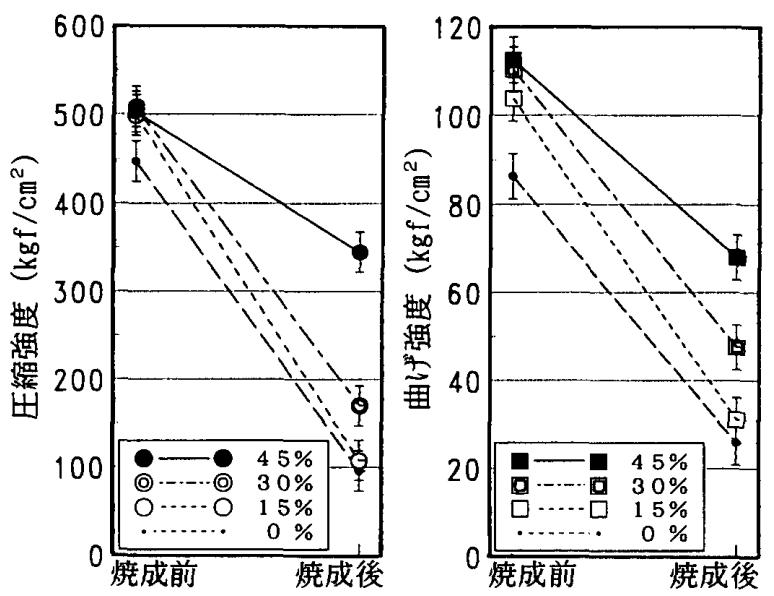

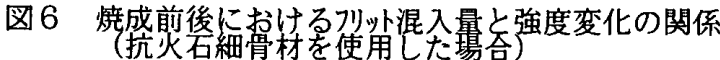

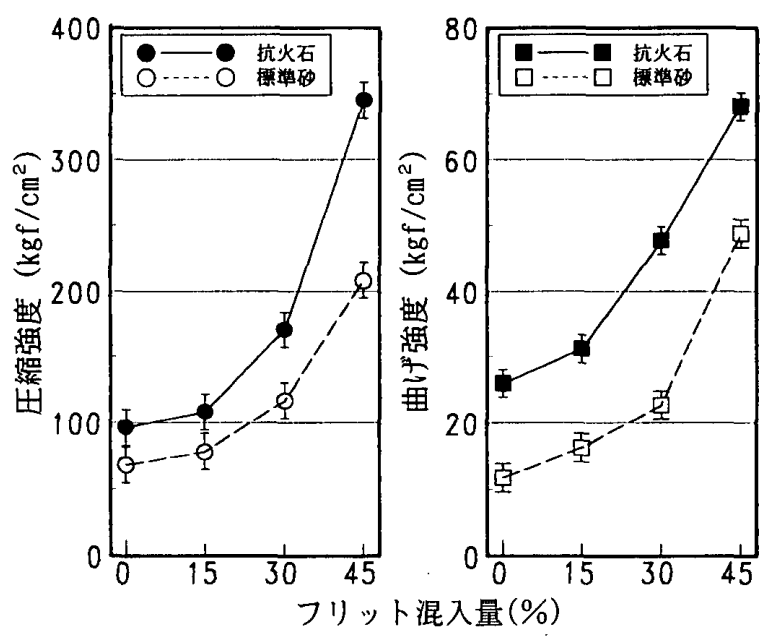

図7細骨材種類执よびリッ混入量と 压縮・曲強度の関係 
リットの混入量が $30 \%$ 以上になるとフリット(3)およびフ リット(1)が顕著な影響を示していることが確認できた。 次に図 10 に細骨材の種額別の焼成前後における試験 体の長さ・重量変化を示す。いずれも試験体乾燥後焼成 前の値を基準としてその增減を百分率で示している。ま ず重量変化であるが、標準砂および抗火石ともに試験体 の乾燥および焼成による重量の减少が見られる。乾熉に よる减少はセメントモルタル中の自由水が脱水している ためと思われる。また焼成による重量減少は試験体が焼 成される際に結晶水が失われることによるものと考えら れる。焼成による重量減少よりも乾燥によるほうが2\%程 度大きく、セメント硬化物中の自由水の多さがうかがえ る。次に長さ変化であるが、標準砂の場合は膨張してい るが、抗火石の場合は逆に収縮しており、焼き締まる傾 向が認められる。この傾向はフリットの湿入量には影響 されておらず、細骨材自身の性質によるものと思われる。 特に標準砂の場合は焼成後重量が減少しているにもかか わらず長さが膨張しているのは、標集砂の主成分である

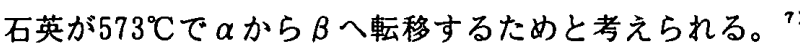
以上の実験より、セメントモルタルのセラミック化 （以後セラミック化モルタルと呼ぶ）に使用する細骨材 として抗火石が有効であることが確認された。またフリ ットの種頽では(3)および(1)がよく、その混入量は $30 \%$ 程 度から顕著な効果が得られることが明かとなった。

なお砂セメント比が1.75の抗火石モルタル（水セメン 卜比 $38.5 \%$ ）にフリット(3)を $\mathrm{F} / \mathrm{C}=30 \%$ 混入し、アミノス ルホン酸系の高性能AE减水剂を対セメント重量比で $3 \%$ 添加し成形した試験体を、 $940^{\circ} \mathrm{C} て ゙ 2$ 時間焼成したのち、 気温 $20^{\circ} \mathrm{C}$, 相対湿度 $60 \%$ の湿空中で保存した試験体の焼 成後の材龄91日までの経過日数と压縮・曲げ強度变化を 図 11 に示す。これより焼成した試験体の王縮・曲げ強 度は長期材齡においてもほほ安定していることがわかる。

\section{2.セラミック化モルタルの調合と混和材の墖討}

\subsection{1. 実臨概要}

前節2.1.においてセメントモルタルにフリットを混入 することによるセラミック化の可能性が確認できた。そ こで本節ではセラミック化に最適となるモルタルの調合 と混和材の影響を調べることを目的として、(1)セメン トに対する細骨材の重量調合比(以下、砂セメント比と呼 び、S/Cで表す)拉よぴ(2)シリカ系混和材であるシリカ フュームの添加量の検討を行い、さらには (3) シリカフ ュームの使用とフリットの混入量の関係についての影響 を調べた。

\subsection{2. 使用材衼}

実験に使用した材料は前節2.1.に準ずるが、細骨材は 最大粒径 $0.5 \mathrm{~mm}$ 以下の抗火石(単位容積質量 $: 1.24 \mathrm{~kg} / \ell$. 柤粒率:1.10)を使用し、またフリットは先の実験で比較 的良好な結果を示した屈伏点が $580^{\circ} \mathrm{C}$ の(3)使用した。

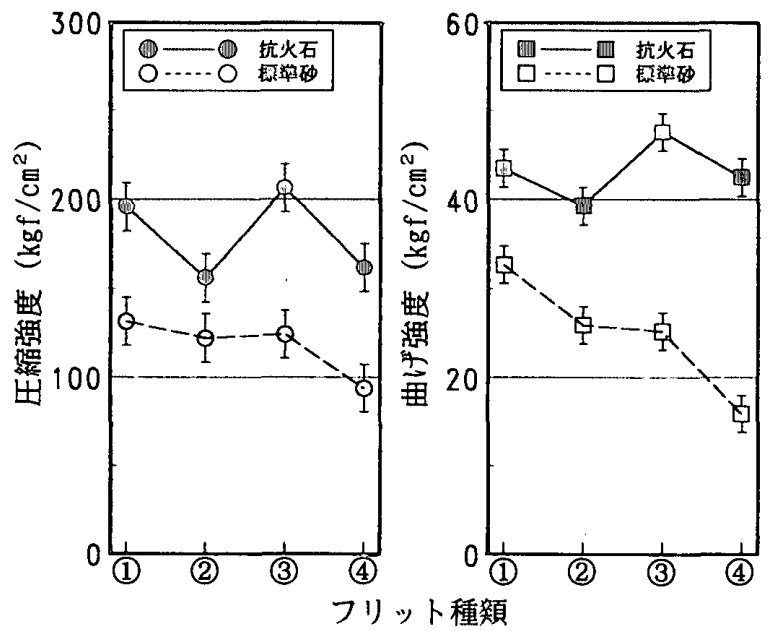

図8 細骨材種類およびフリ外種㥧と圧縮・曲げ強度の関係

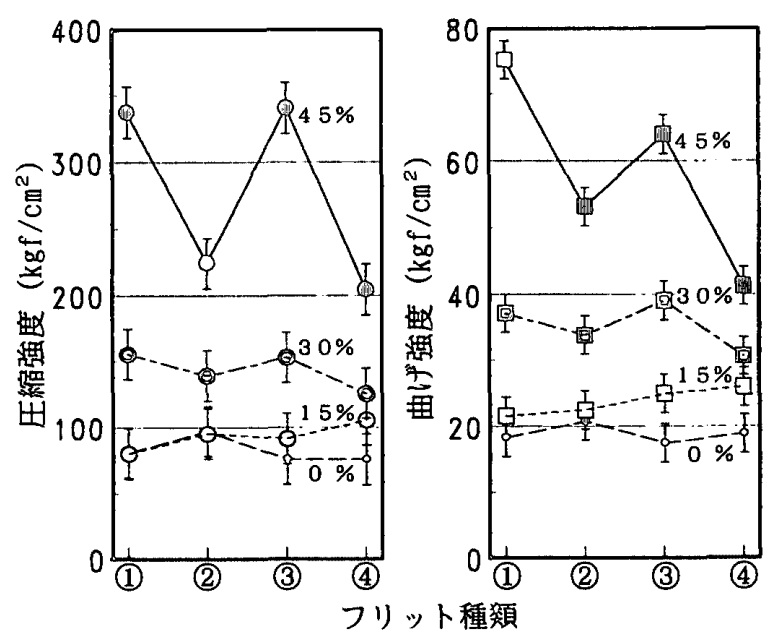

図9 フリッ卜種額およびフリ惃入量と王縮・曲げ強度の関係

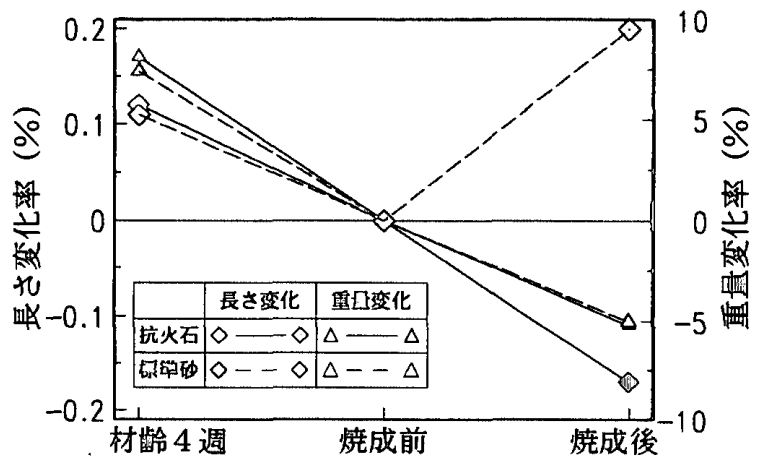

図 10 焼成前後における試跧体長さおよび 重量変化

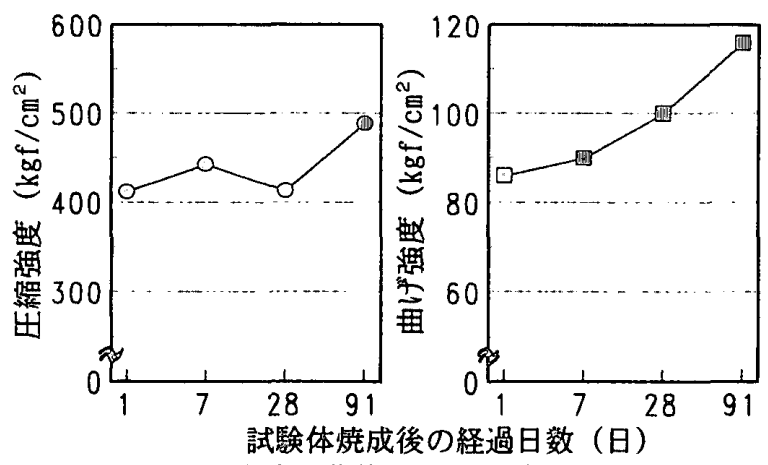

図 11 焼成後試験体王縮・曲訬強度経時变化 


\begin{tabular}{|c|c|c|c|c|}
\hline \multicolumn{5}{|c|}{ 表4＜wide>試験体調合表 } \\
\hline 実 驗 調合比 & $\begin{array}{l}\text { 砂丈水皆 } \\
(\mathrm{S} / \mathrm{C})\end{array}$ & \begin{tabular}{|l|} 
涉加-4 \\
添加量 \\
\end{tabular} & \begin{tabular}{|l|} 
フリッ下 \\
湿入量 \\
\end{tabular} & $\begin{array}{r}\text { 水結合材 } \\
\text { 比哋 }\end{array}$ \\
\hline （1）砂冰比 & $\left\{\begin{array}{l}3 \\
\text { 段 } \\
\text { 階 }\end{array}\left\{\begin{array}{l}1.25 \\
1.5 \\
1.75\end{array}\right.\right.$ & - & 20\%一定 & $40 \%-$ \\
\hline (2) 沙力 & 1.25一定 & 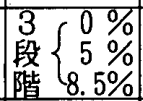 & 10\%一定 & \begin{tabular}{|l|l}
$38 \%$ & $1 / C$ \\
$36 \%$ & $38 \%$ \\
$35 \%$ & 定 \\
\end{tabular} \\
\hline (3) フリット混入量 & 1.25一定 & $5 \%$ 一定 & $\begin{array}{c}3 \\
\text { 段 } \\
\text { 阹 }\end{array}\left\{\begin{array}{l}10 \% \\
20 \% \\
30 \%\end{array}\right.$ & $37 \%-$ \\
\hline
\end{tabular}

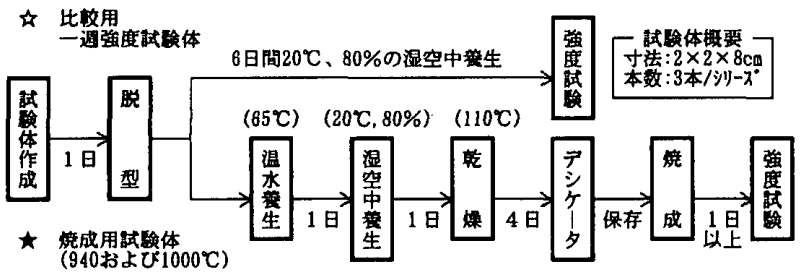

図 12 試験体処理の流れ図

さらに高性能 A E 減水郕としてアミノスルホン酸系のも のを使用し、シリカフュームは比表面樌 $200,000 \mathrm{~cm}^{2} / \mathrm{g}$, 平均粒径 $0.15 \mu \mathrm{m}$ の粉末状のものを使用した。

\subsection{3. 試験体の作成}

試験体は前項 (1)〜 (3)の各実験項目について表 4 に 示す調合により作成した。また減水剤添加量は各実験と も対セメント重量比で $4 \%$ と一定にして行った。練り混 ぜは前述の図 2 に示すモルタルの練り混ぜ方法に準じた が、2 次練りを 60 秒 $\rightarrow 20$ 秒休止 $\rightarrow 300$ 秒として計 9 分間の 練り混ぜを行った。試験体は前節と同様に $2 \times 2 \times 8 \mathrm{~cm}$ の角 柱状試験体を焼成温度 $940^{\circ} \mathrm{C} ， 1000^{\circ} \mathrm{C}$ ならびに比較用の 1 週強度用の3 通りについて各 3 本づつ作成した。これら を図 12 に示すごとく養生，乾燥および焼成を行った。

\subsection{4.試験体の焼成および試験}

試験体の焼成も前節にほぼ同じであるが、焼成温度を 2 時間で $940^{\circ} \mathrm{C}$ まな $1000^{\circ} \mathrm{C}$ の 2 通りとなるように設定 するとともに、各焼成時間は 2 時間とした。試験項目も 前節に従い、試験体焼成前後での圧縮・曲げ試験を行った。

\subsection{5. 秒セメント比 $(S / C) の$ 影盟}

図 13 に試験体焼成後の強度変化を示す。 $S / C=1.5 お$ よび1.75では、 $940^{\circ} \mathrm{C} の$ 焼成においては試験体内の組織が 壊れ、強度が低下しているが、さらに温度を上げ $1000^{\circ} \mathrm{C}$ で焼成すると焼結し再び一週強度と同等か、それに近づ く程度まで強度が回復する傾向が見られた。これに対し $S / C=1.25$ の場合は、焼成後の強度が增加することが確認 できた。これはセメントに対する砂の割合が減ったため、 高性能 A E 減水剂の添加によりモルタルの流動性が増す 結果、試験体内の空隙が減るような混練が行われ、緻密 性が高まったためと思われる。以上よりセラミック化に 最適な砂セメント比は1.25ということが確認された。

\subsection{6.シリカフューム添加の影蠁}

因14 にシリカフュームを添加したセラミック化モル タルのシリカフューム添加量とフロー値および単位容積

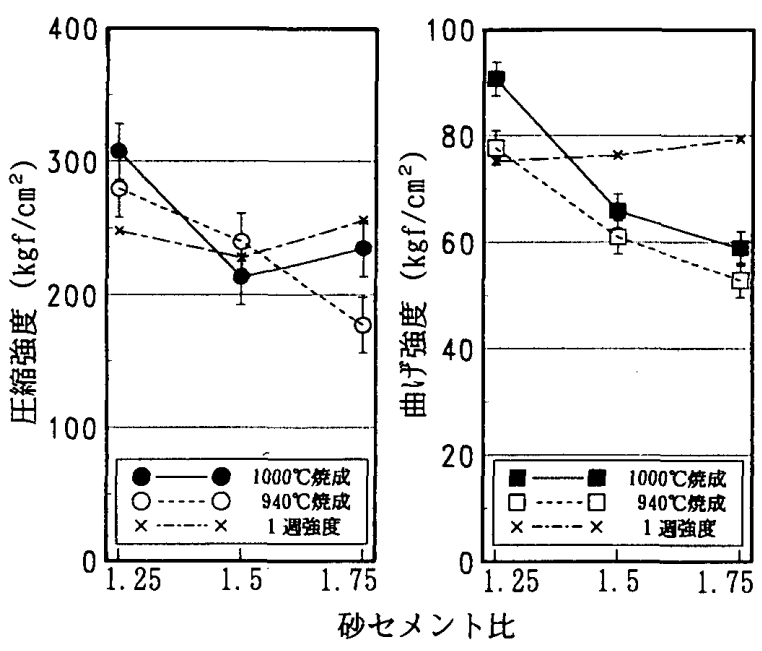

図 13 砂セメント比と区縮・曲げ強度の関係

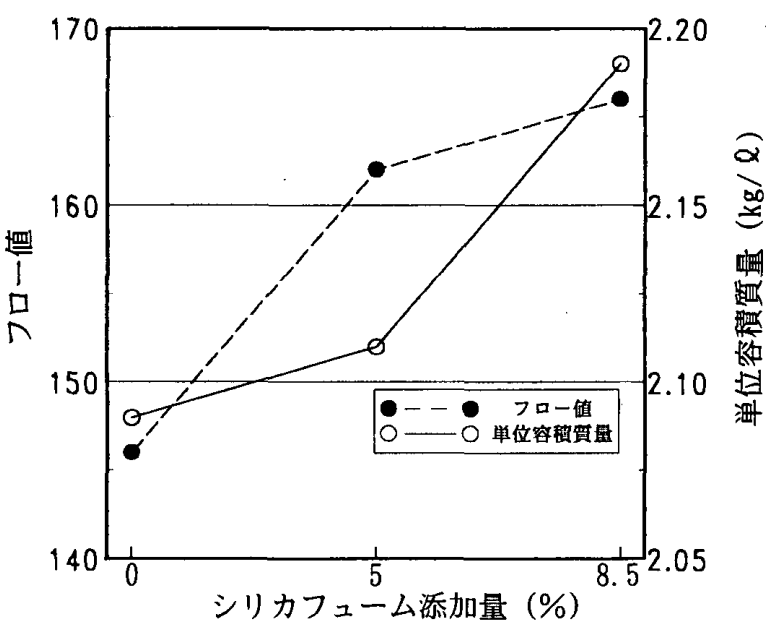

図 14 シリカフューム添加量と

フロー値および単位謇積質量の関係

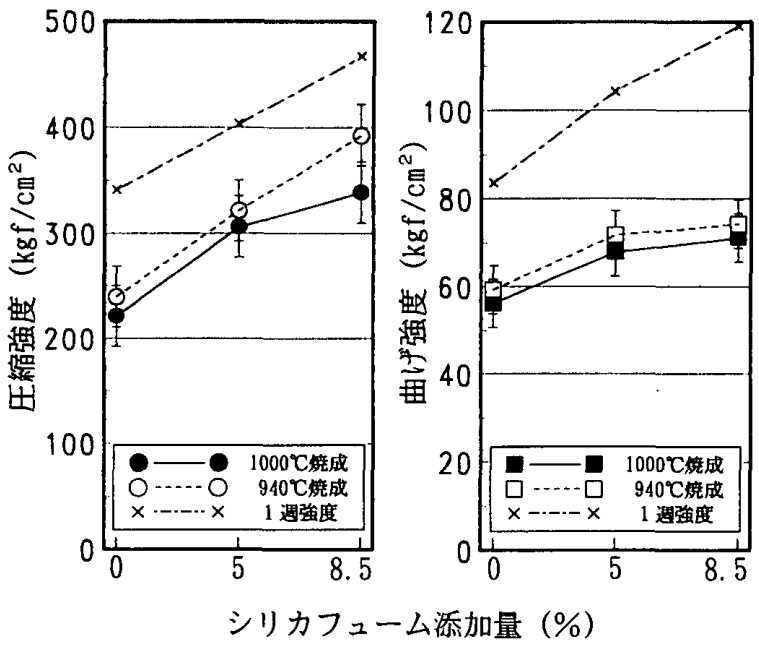

困 15 シリカフューム添加量と王縮・曲げ強度の関係 
質量の関係を示す。これよりシリカフューム添加量が增 えるほどその流動性が大きくなり、同時に単位容積質量 も增加していることがわかる。これは抗火石の粒形が角 ばっているために骨材間の摩擦が大きくなりモルタルの 流動性を損なっているが、粒形が球に近いシリカフュー ムを添加することで流動性がよくなり、単位水量を減ら し密実な試験体とすることが可能で、施工性の向上につ ながるといえる。また図 15 に、これらを成形し锛成し た後の試験体強度試戨結果を示す。これよりシリカフュ 一ム添加量が多いほど、焼成後の強度の増加が見られ、 焼成による試験体の爆裂等の問題も生じなかった。

以上よりシリカフュームを5〜8\%程度添加することに より、モルタルの流動性を向上させ、焼成後の強度增加 を図ることが可能であることが確認された。

\subsection{7.シリカフュームの使用とフリットの混入圈の関係}

図 16 にシリカフュームを対セメント重量比で5\%添加 し、フリットの混入量を変化させた試験体を、 $940^{\circ} \mathrm{C} ま$

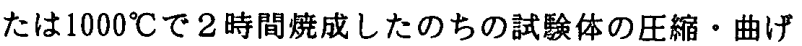
強度の結果を示す。これよりフリットの混入量が20\%以 上の場合は王縮・曲げ強度ともに焼成前の一䓢強度とほ

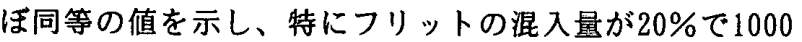
Cてで焼成した場合は、王縮・曲げ強度ともに焼成前の一 週強度を上回った。またフリットの混入量が $30 \%$ の場合、 焼成温度にかかわらず焼成前の一週強度を上回り、特に $1000^{\circ} \mathrm{C}$ の焼成では大幅に強度が增加することが確認され

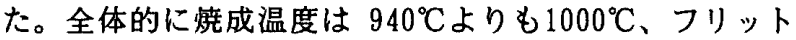

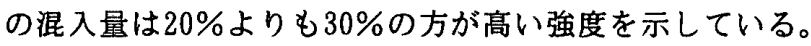
これは焼成温度が $1000^{\circ} \mathrm{C}$ の方がフリットも溶融しやすく、 溶融量が多くなり、これらが試験体中の空吵を埋めて焼 結が進むためではないかと思われる。

以上の実鈳より、セラミック化モルタルに最適な調合 は、砂セメント比を1.25程度のセメント量の多いものと し、同時にシリカフュームを $5 \sim 8 \%$ 程度添加すること が効果的であった。特にフリットの混入量は $20 \%$ 程度以 上が適当であった。さらに焼成温度も $940^{\circ} \mathrm{C}$ よは 1000 ${ }^{\circ} \mathrm{C}$ と高温の方が良い結果を示した。

\section{3 .測色实趁}

本章ではセラミック化モルタルの表面に色婇薬を施棌 し焼成することにより、意匠材としての利用の可能性を 調べることとし、（1）実験に使用する色紬薬の焼成温度 の検討および (2)色婇薬により施婇したセラミック化モ ルタルの測色を行った。

\section{1.色䌷菲の蛻成温度の検討}

\section{1 .1 . 实驗概要}

本実験は色婇薬の施婇に最適な焼成温度を調べること を目的としたもので、表 $5^{\text {8) }}$ に示す標菹フリットに発色 剂を混入した 6 色の婇薬を用意し、これらをそれぞれ白 色素焼きタイルに施嬏し、5通りの焼成温度で焼成した

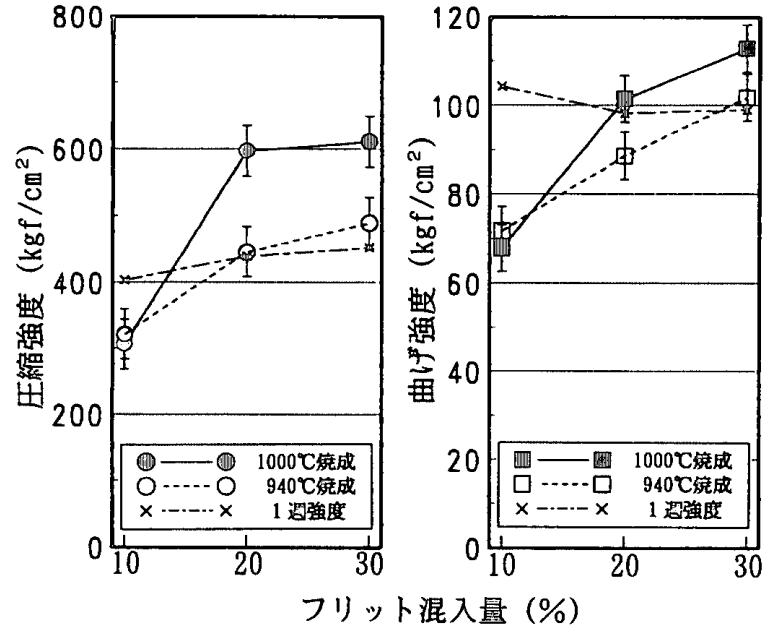

图 16 フリット混入量と圧縮・曲げ強度の関係

表 5 色婇薬調合表(重量調合比による\%)

\begin{tabular}{|c|c|c|}
\hline 㖃準フリットA & 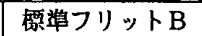 & 螇準フリット C \\
\hline 白 81.1 & 炭酸り $-\xi^{*} \quad 22.8$ & ほう砂 68.6 \\
\hline 18. 9 & 酸 化敛 40.0 & 石灰石 \\
\hline------- & 珪 石 37.2 & 23.2 \\
\hline 砘 $\square$ & 2:マアガン紫婇 + & 3:アン㔚黄秞 \\
\hline 摽準》川ットA 74.6 & 標準ㄱ川y快 65.9 & 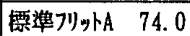 \\
\hline 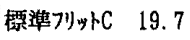 & 摽準刐帅C 28.3 & 標準刏师C \\
\hline カオリン & カオリン & カオリン \\
\hline 酸化 铁 & 酸マンガン & 酸化アン手さ \\
\hline------- & 酸化בn* M & ---- \\
\hline 4:トルコ青釉 $\triangle$ & 5 :銅 緑 劧 0 & 6:クロム赤釉 $\nabla$ \\
\hline 僄進杪ットB & 磦染壮外A 76.3 & 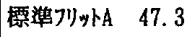 \\
\hline 磦準ㄱy, & 標準刐,トB & 47.3 \\
\hline カオリン & 骠準刐ットC & カオリン \\
\hline 5.7 & カオリン & 重加酸加邡 2.6 \\
\hline 炭酸銅 & 炭酸鋮 & $-\ldots$ \\
\hline
\end{tabular}

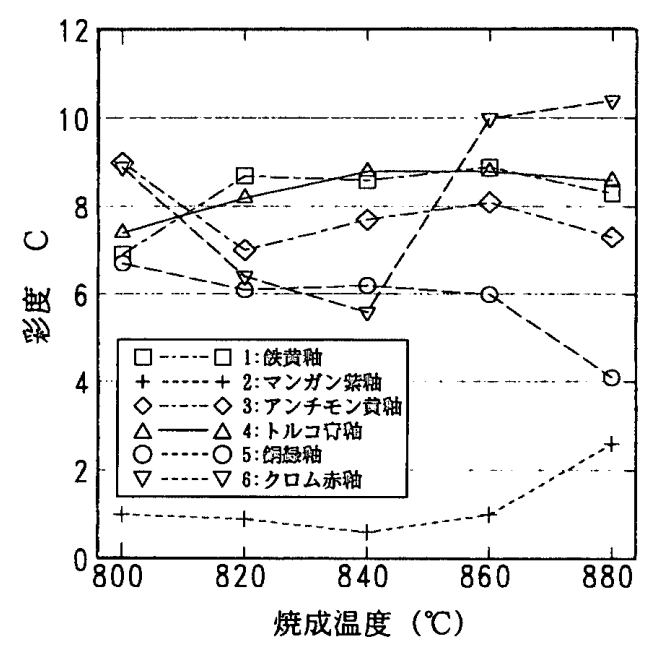

図 17 焼成温度と彩度の関係 
ものの彩度を調べることにより、施釉に最適な焼成温度 の検討を行った。

\subsection{2.色秞薬の調合および施釉方法}

色釉薬は表 5 に基づき計 $100 \mathrm{~g}$ となるように重量調合で 行った。調合した粉末状の釉薬は蒸留水を加えて稳濁液 とし、これを図 18 の (a) に示す、 $25 \mathrm{~mm}$ 角，厚さ $4.65 \mathrm{~mm}$ の白色タイルの中央に直径 $25 \mathrm{~mm}$ 程度の円形となるように 筆で施釉した。これを $110^{\circ} \mathrm{C}$ の定温乾燥器中で恒量とな るまで乾燥させた。各釉薬ともに各焼成温度に対して 4 枚ずつ計 120 枚の施釉タイルを作成した。

\subsection{3.焼成および測色方法}

竼成には前章 2 ．セメントモルタルのセラミック化実 験と同様にマッフル炉を使用した。焼成温度は 800,820 , $840,860,880{ }^{\circ} \mathrm{C}$ の 5 通りとし、各焼成温度毎に24枚の施 粙タイルをランダムにパレットの上に載せ、常温のマッ フル炉中に挿入した。その後 110 分間で炉内温度を各焼 成温度まで上界させ、2 時間温度を維持して焼成した。 焼成後は炬内で自然放泠し、炬内温度が $150^{\circ} \mathrm{C}$ 以下にな ったのち炉から取り出した。測色は施釉タイルが十分に 冷却されたのち、携帯用分光色差計（測定径 : $14 \phi \mathrm{mm}$, 以後色美計と呼ぶ）を用い、各施釉タイルの中央部を三 刺激値 $\mathrm{X}, \mathrm{Y}, \mathrm{Z}$ 抢よび三属性 $\mathrm{H}, \mathrm{V} ， \mathrm{C}$ により測色し、そ の平均値を求めた。

\subsection{4. 実験結果}

因 17 に焼成温度による色釉薬の彩度変化を示す。全 体的に焼成温度が $820^{\circ} \mathrm{C}$ から $860^{\circ} \mathrm{C}$ の間では彩度は上年す る傾向にあるが、焼成温度が $880^{\circ} \mathrm{C}$ と高くなると彩度は

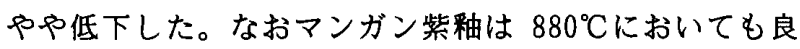
好な彩度を示した。これらの結果から、色の鲜やかさを 表す彩度の值は $860^{\circ} \mathrm{C}$ 付近が最も高く、この温度が本実 験で使用した色釉薬の最適施釉温度であると考えられる。

\section{2.セラミック化モルタルへの施釉実験}

\subsection{1. 実験概要}

次に前節3.1. で使用した色釉薬をセラミック化モル夕 ルに施釉し、烧成した場合の施釉状態および焼成時間と 色釉薬の生地への浸透状況について検討した。

\subsection{2.試験体の作成および施釉方法}

実験に使用した試験体は最大粒径 $2.0 \mathrm{~mm}$ の抗火石を用 いた $\mathrm{S} / \mathrm{C}=1.75$ のルタルに、フリット(3)を対セメント重 量比 $30 \%$ を混入したものとし、これにより $2 \times 2 \times 8 \mathrm{~cm}$ の角柱 型試験体を計 18 本作成し、これを $940^{\circ} \mathrm{C} て ゙ 2$ 時間素焼した。 これに前述の色釉薬を試験体 1 本につき 1 色を割り当て、 各試験体の任意の 1 面に対し㘡 18 の（b)に示すように 3 箇所を施嬏厚さ $0.5 \mathrm{~mm}$ となるように筆で施釉した。

\subsection{3.試験体の焼成および測色方法}

施釉された試験体は $110^{\circ} \mathrm{C} の$ 定温乾燥器中で恒量とな るまで乾燥させたのち、 6 色を一組としてランタムにパ レットに載せ、常温のマッフル炉中に挿入した。これを
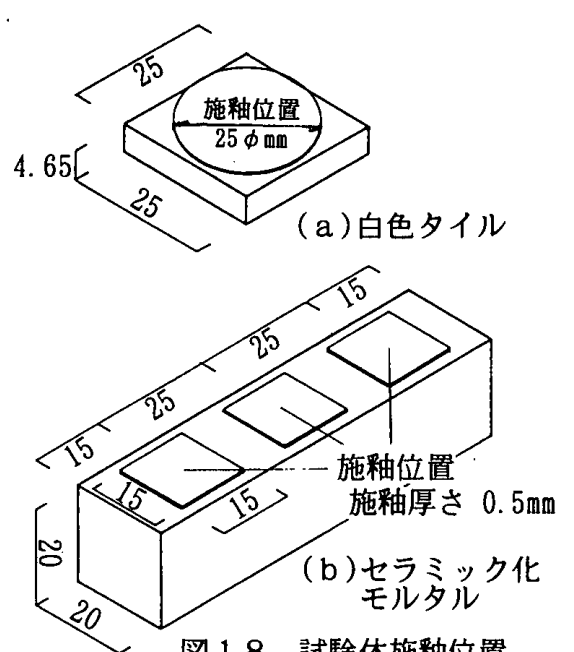

図 18 試験体施釉位置

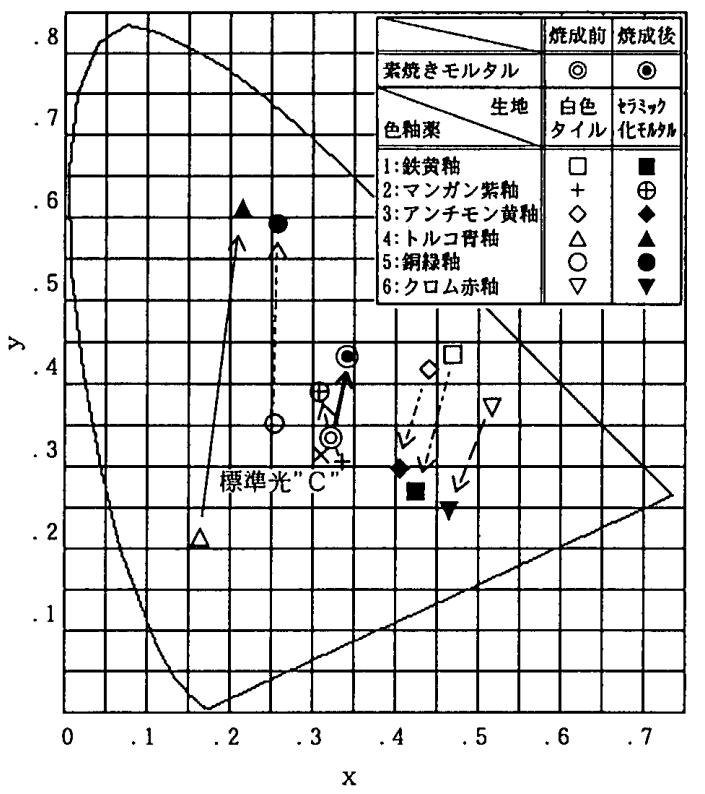

因 19 試験体測色結果(色度図)

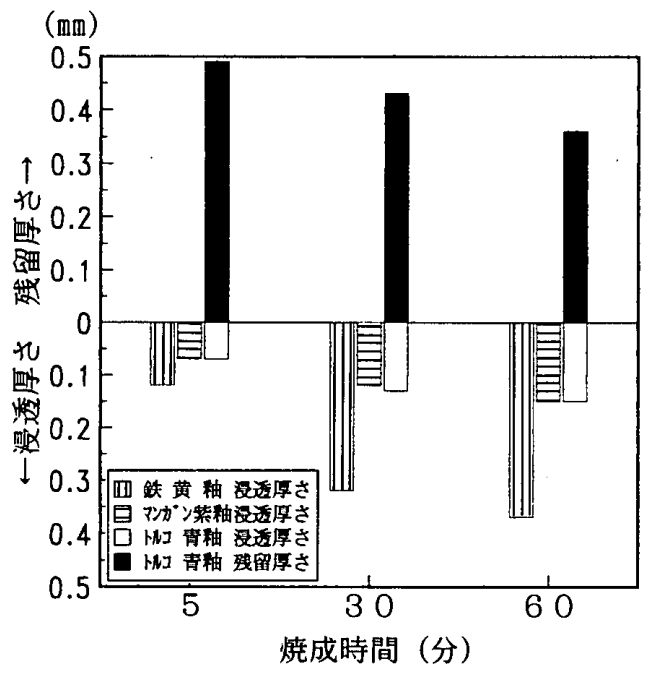

図20焼成時間と釉薬浸透厚の関係 


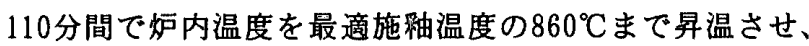
焼成時間を 5 分, 30 分, 60 分の 3 通りとして温度を維持し 焼成した。その後炉内で自然放冷させ、炉内温度が 150 ㄷ以に下がったところで妒から取り出した。

試験体の測色は試験体の素焼きを行う前後および色婇 薬を施釉・焼成後に図 18 の(b)に示す 3 力所の中央部 を色差計により測色し、その平均値を求めた。

また色釉薬の生地モルタルへの漫透状況を調べるため、 測色した試験体 3 力所のそれぞれの中央部をダイヤモン ドカッターにより切断し、試験体表面から色跀嵲が漫透 した位掼までの距離および色跀蒋の残留厚さをノギスに より測定し、その平均值を求めた。

\subsection{4.実唋結果および考察}

図 19 に各色釉薬を試験体に施紬し、 $860^{\circ} \mathrm{C} て ゙ 30$ 分間焼 成した後の湘色結果を示す。また前節 3.1 . 色邹薬の焼成 温度の検討において、各色婇蒋を白色素焼きタイルに施

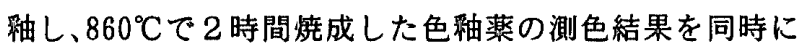
示す。ここで図中央の×字は標準光"C”を示している。

これより色跀蔝は矢印の向きが示すように、生地の違 いによりその発色の程度を变化させることがわかる。さ らに図上の○印はモルタル試験体を $940^{\circ} \mathrm{C} て ゙ 2$ 時間素焼 きする前の色を、⑩印は素焼きした後の色を示し、モル タル試験体は素焼きすることにより色相 $\mathrm{H}$ が黄赤の方 向に変色し、同時に彩度が上昇することがわかる。この ○から(10)の矢印の向きと、生地の遧いによる色袖薬の 変色の矢印の向きがほぼ同じ方向に移動していることか

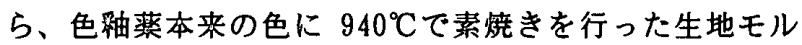
タルの黄変が影偣することを敲付けている。これにより セラミック化モルタルの施婇には単に色婇蘶だけでなく、 生地の色が大きく影䭗することでさらに奥行き深い色合 いを出せることが確認できた。

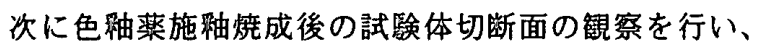
鉄黄婇，マンがン紫婇およびトル青釉の焼成時間と婇薬の浸 透厚さの変化を、またト川青跀に閣しては試験体表面に 残った婇葲の残留厚さの変化を図 20 に示す。ここで焼 成時間が 5 分の場合はある程度神蔡は熔けて流れ、焼成 時間が30分および60分と長くなるほどモルタル生地に深 く釉薬が浸透していることが確認された。しかし焼成時 間が長くなり釉薬の漫透が進むにつれて、表面の掿薬の 残留厚さが少なくなりガラス質の光沢は逆に少なくなる ことが確認された。

以上の実験からセラミック化モルタルは焼成により無 彩色から黄赤の色相を帯び、彩度が上䄯することが判明 した。また色釉䓠については、860 $\mathrm{C}$ 周辺に最適施紬温度 が存在することが確認された。さらに抗火石モルタルへ の施婇実験では、 $860^{\circ} \mathrm{C} て ゙ 30$ 分程度焼成することで色婇䓠 が渵遍なく生地に漫透し安定した施紬面となることが確 認された。以上よりセラミック化モルタルの表面には色
釉薬による施釉が可能であり、基材を生かした骨行き深 い着彩が可能であった。

4.まと的

本研究ではセメントモルタルにフリットを湿入するこ とにより、焼成後の強度低下を抑制しセメントモルタル のセラミック化を図ることが可能であることが確認され た。これは焼成によりセメント水和物が結晶水を失うこ とで強度が低下するが、溶融したフリットがこれを補い、 強度を維持するためと考えられる。このセメントモルタ ルのセラミック化を図るために以下の知見が得られた。

1.フリットの種㱛は屈伏点が $580^{\circ} \mathrm{C}$ 以下のものが適切。

2. フリットの混入量が多い程焼成後の残存強度は高い。

3.細骨材には抗火石が適切。

4. 今回使用した抗火石の場合、その調合比は砂セメント 比で1.25程度と、セメント量が多い方が焼成後の残存 強度が高い。

5. シリカフュームを対セメント重量比で 5 〜 $8 \%$ 添加す ることでモルタルの流動性を增し、焼成後の強度上昇 を図ることができる。

6. シリカフュームを添加した場合には、フリットの混入 量は対セメント重量比で $20 \%$ 以上が効果的である。

7. 焼成温度は $1000^{\circ} \mathrm{C}$ 程度の高温の方が残存強度が高い。

8. 今回使用した色嬏盌の場合、セラミック化モルタルの 施袖に最道な焼成温度は $860^{\circ} \mathrm{C}$ かつ焼成時間は 30 分程 度である。

なお本研究は、東京都立大学の平成 3 年度 修士論文 （日本建築学会㦘秀修士論文賞受賞）として研究したも のを中心にまとめたものであり、これらの研究に協力頂 いた卒論生の中島聡一、赤類竜也両君に謝意を表します。

厸势文敷

1)W，チェルニン著,德根吉郎訳：建設技街者のた氻のセ タント・コンクリート化学, 技報堂, pp.157-161,1969.12 2)大門正幾：新種セカントと化学結合セラミックス,セカ ント・コンクリート,No.498,pp.26-29,1988.8

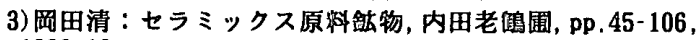
1990.12

4)木下嶑城，小川留太郎：岩石猞物，保育社, pp.119,1967.1

5)魚本健人：分割方式によるコンクリートの悢りまぜ方法 に関する基檗研究, コンクリート工学、Vol.20,No.9,pp.99 $-113,1982.9$

6) 岸谷孝一，伊東靖郎，加賀数治，山本康弘：SECユンク

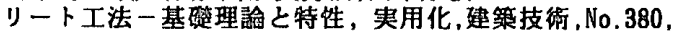
pp. 87-104,1983.4

7) 日本セラミックス協会：セラミック材㘰、日本セラミッ クス協会, pp.68-72,1993.3

8)素本洋一：セラミックス手蜄，技報堂,pp.470, 1972.1

9) 三田虹行，大沢清八，浦部和㑯，山本康弘，島田良一：セラ ミック化コンクリートに関する基酸的研究，日本起築学会 大会学術謧演梗概集 $\mathrm{A}, \mathrm{pp} .461-462,1991.9$

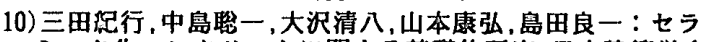
ミック化コンクリートに関する基颂的研究、日本㛬築学会 大会学術㒛演梗相集 A,pp.251-252,1992.8

11）三田㶤行,赤瀬竜也,大沢清八,山本康弘：セラミック化 コンクリートに関する基砗的研究（その1。混和材および

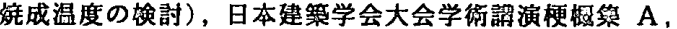
pp. 349-350, 1993.9

12）赤瀨童也，三田紀行，大沢清八，山本鹿弘：セラミック化 コンクリートに関する基碳的研究（その 2 .フリット理䅡

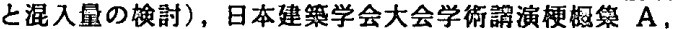
pp. 351-352, 1993.9

（1994年 9 月 8 日原稿受理，1995年 2 月 8 日採用決定） 